\title{
Survey on thermal environments in bathrooms and elderly behavior while bathing in old residential buildings in Nanjing, China
}

\author{
Pengcheng Shi ${ }^{1,}$, Yonghui $\mathrm{Li}^{1}$, Yuan Ying ${ }^{1}$, and Shuichi Hokoi ${ }^{2 *}$ \\ ${ }^{1}$ School of Architecture, Southeast University, 210000 Nanjing, Jiangsu Province, P.R. China \\ ${ }^{2}$ Architecture Internationalization Demonstration School, Southeast University, 210000 Nanjing, Jiangsu Province, P.R. China
}

\begin{abstract}
Bathing is a typical daily behavior among Chinese elderly people, which causes large thermal environmental fluctuations especially in winter. Rapid fluctuations of the thermal environment can lead to a drastic change in human blood pressure and may cause accidents while bathing. The most common style of Chinese bathing is showers. Information on the thermal environment during bathing is limited, making analysis difficult. This study aims to understand the current situation of bathing in old residences in Nanjing, China. To examine elderly bathing behaviors and thermal environments in bathrooms during bathing, we monitored the thermal environment in three elderly families and administered a questionnaire survey from which 49 responses were obtained. Results were categorized into environmental and personal factors that affect blood pressure during bathing. In winter, the temperature in a bathroom is often below $10^{\circ} \mathrm{C}$. A heating device is installed close to the head (87\%); thus, the thermal environment is vertically non-uniform (air temperature difference often exceeds $10^{\circ} \mathrm{C}$ ). Most elderly individuals bathe for less than 30 minutes and the rise in air temperature often exceeds $10^{\circ} \mathrm{C}$. This information will be used as the boundary conditions for thermo-physiological models that can quantitatively assess the impact of the environment on the elderly, and for the renovation of bathrooms.
\end{abstract}

\section{Introduction}

In our daily lives, activities like sleeping, eating, and bathing are conducted in a variety of thermal environments. The bathroom is a space where the thermal environment significantly changes when used. Drastic changes in the thermal environment will affect human blood pressure. When the elderly experience a sudden temperature change on their skin during bathing, the human hypothalamus regulates the neuromodulation and endocrines, causing blood vessels near the skin to contract or dilate, resulting in changes in blood flow and blood pressure. By regulating heart rate and vasodilation, the human body regulates the overall blood pressure and blood flow rate. At the same time, it regulates body heat balance. As physical function of the elderly declines, the ability to respond to severe thermal environmental changes is also weakened. Therefore, changes in the thermal environment during bathing will lead to severe changes in blood pressure and blood flow rate, which may easily induce various cardiovascular and cerebrovascular diseases.

The accelerated aging of the population has increased the accident rate in bathrooms. Tasuzuki et al. [1] and Kubo et al. [2] reported blood pressure changes during bathing. Asakawa et al. [3] and Tochirara et al. [4] measured the blood pressure, pulse rate, and temperatures of various parts of the body of elderly during bathing. The results showed that the older the person, the greater the fluctuation of blood pressure, and drastic changes in blood pressure can easily lead to accidents. In China, there are no statistics on the deaths of elderly people while bathing. However, accidents are often characterized by falls, syncope, cerebral hemorrhage, etc., and $45 \%$ of the elderly are hospitalized due to falls in China. Among them, internal causes account for 39\%, external causes for 39\%, and unknown reasons for $16 \%$ of accidents [5]. A majority of deaths are caused by cardiovascular and cerebrovascular diseases.

Regulations on the indoor thermal environment in China are mainly focused on living spaces such as bedrooms and living rooms, and the bathroom is often neglected. The thermal environment in the bathroom while bathing is significantly different as compared to other living spaces. There are three main forms of temperature change [6]: temperature gradients, periodic temperature changes, and uneven thermal environment. At the same time, body thermal balance is strongly related to environmental parameters such as air temperature, mean radiant temperature, and relative air

\footnotetext{
* Corresponding author: hokoi@seu.edu.cn
} 
velocity[7,8,9]. In this regard, we collected 49 questionnaires and measured the thermal environment in three typical bathrooms to identify environmental and personal factors that typically affect blood pressure in the elderly when bathing.

This research will provide fundamental information for the renovation of existing bathing rooms in China. At the same time, it will guide design processes of new bathrooms from an environmental control point of view. This will help optimize the environment of bathrooms in old residences and provide a scientific basis for the design of healthy buildings.

This survey is mainly aimed at self-care elderly in the community. As blood pressure changes are closely related to age, the subjects were divided into middle-aged elderly people aged 55-65, elderly people aged 66-75, and older elderly people aged $76-85$.

\section{Method of Research}

\subsection{Design of research structure}

Previous studies have largely demonstrated a negative correlation between environmental temperature and blood pressure, that is, blood pressure increases when temperature decreases $[10,11,12]$. Personal difference is also an important factor influencing blood pressure changes.

Therefore, aiming at clarifying the effects of thermal environment and human behaviors on the health of the elderly through blood pressure changes during bathing, we designed our research structure. This research consists of (1) measurements of environmental conditions, and (2) a questionnaire survey.

\subsection{Measurements of environmental conditions in bathroom}

In order to characterize environmental conditions in bathrooms in old residences, we measured temperatures at several locations in the bathroom.

The results of the questionnaire survey were also used to clarify the influence of heating devices, ventilation, open/closed windows, etc.

\subsection{Questionnaire survey}

In the questionnaire survey, we asked questions about items in two categories. The first related to the heating device, size of the bathroom, and equipment condition in the bathroom, etc. The second category related to bathing habits such as device use, bathing time, posture change, etc.

\subsection{Surveyed area and climatic conditions}

We conducted field surveys in the old housing complexes of Chengdu Chengxian Community and Lanyuan Community in Nanjing. Nanjing is a city in southern China and is representative of East China (Fig. 1). The annual change of outdoor temperature in Nanjing is presented in Fig. 2.

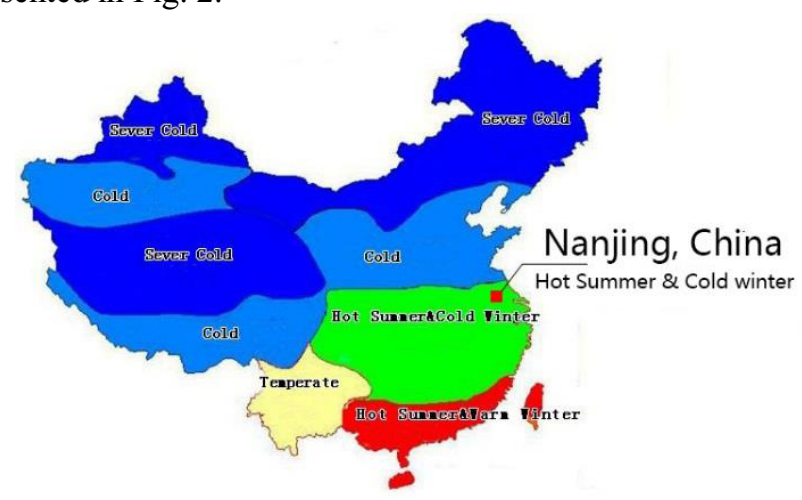

Fig. 1 Climate zone of China

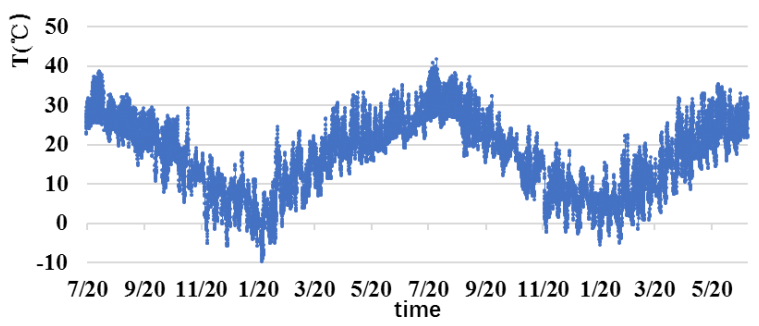

Fig. 2 Outdoor temperature in Nanjing for two years (from 2015 to 2017 )

\subsection{Surveyed housing complexes}

The survey was conducted in the old housing complexes near Southeast University. A total of 12 complexes were investigated (Figure 3 and Table 1). All of the surveyed apartment houses had no insulation.
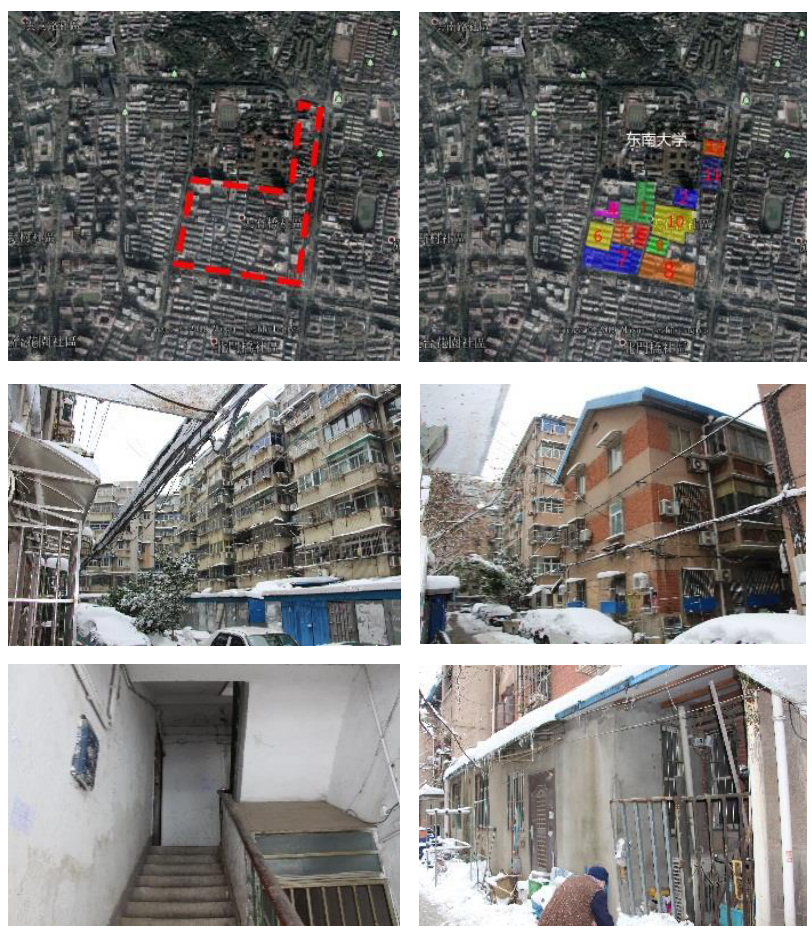

Fig. 3 Surveyed housing complexes 
Table. 1 Surveyed housing complexes

\begin{tabular}{|c|c|c|c|}
\hline No. & Feature & Description & Structure \\
\hline \multirow{4}{*}{1} & $\begin{array}{l}\text { Name of } \\
\text { complex }\end{array}$ & $\begin{array}{l}\text { Zhen Alley } \\
\text { Complex }\end{array}$ & \multirow{4}{*}{$\begin{array}{c}\text { Structure: Core } \\
\text { tube frame } \\
\text { structure/sintered } \\
\text { concrete as } \\
\text { maintenance } \\
\text { structure/Retrofit } \\
\text { elevator }\end{array}$} \\
\hline & $\begin{array}{c}\text { Year of } \\
\text { construction }\end{array}$ & 90 's & \\
\hline & Floor/Story & $\begin{array}{c}\text { 7th/multi- } \\
\text { storey }\end{array}$ & \\
\hline & Floor height & $2.7 \mathrm{~m}$ & \\
\hline \multirow{4}{*}{2} & $\begin{array}{l}\text { Name of } \\
\text { complex }\end{array}$ & $\begin{array}{l}\text { Cheng Xian } \\
\text { Complex } 117\end{array}$ & \multirow{4}{*}{$\begin{array}{l}\text { Structure: Core } \\
\text { tube frame } \\
\text { structure/aerated } \\
\text { concrete as } \\
\text { maintenance } \\
\text { structure/high-rise } \\
\text { building }\end{array}$} \\
\hline & $\begin{array}{c}\text { Year of } \\
\text { construction }\end{array}$ & 1997 & \\
\hline & Floor/Story & 33th/tower & \\
\hline & Floor height & $2.7 \mathrm{~m}$ & \\
\hline \multirow{4}{*}{3} & $\begin{array}{l}\text { Name of } \\
\text { complex }\end{array}$ & $\begin{array}{l}\text { Tiger Bridge } \\
\text { Complex } 32 \\
\end{array}$ & \multirow{4}{*}{$\begin{array}{l}\text { Structure: Brick- } \\
\text { concrete structure }\end{array}$} \\
\hline & $\begin{array}{c}\text { Year of } \\
\text { construction }\end{array}$ & 70's \& 90's & \\
\hline & Floor/Story & multi-storey & \\
\hline & Floor height & $2.7 \mathrm{~m}$ & \\
\hline \multirow{4}{*}{4} & $\begin{array}{l}\text { Name of } \\
\text { complex }\end{array}$ & $\begin{array}{l}\text { Tiger Bridge } \\
\text { Complex } 40\end{array}$ & \multirow{4}{*}{$\begin{array}{l}\text { Structure: Brick- } \\
\text { concrete structure }\end{array}$} \\
\hline & $\begin{array}{c}\text { Year of } \\
\text { construction }\end{array}$ & 70’s \&90’s & \\
\hline & Floor/Story & multi-storey & \\
\hline & Floor height & $2.7 \mathrm{~m}$ & \\
\hline \multirow{4}{*}{5} & $\begin{array}{l}\text { Name of } \\
\text { complex }\end{array}$ & $\begin{array}{c}\text { JiangJun Alley } \\
\text { Complex } \\
\end{array}$ & \multirow{4}{*}{$\begin{array}{l}\text { Structure: Brick- } \\
\text { concrete structure/ } \\
\text { sintered brick as } \\
\text { maintenance } \\
\text { structure/Facade } \\
\text { reconstruction }\end{array}$} \\
\hline & $\begin{array}{c}\text { Year of } \\
\text { construction }\end{array}$ & 1990 & \\
\hline & Floor/Story & $\begin{array}{c}5 \text { th/multi- } \\
\text { storey }\end{array}$ & \\
\hline & Floor height & $2.7 \mathrm{~m}$ & \\
\hline \multirow{4}{*}{6} & $\begin{array}{l}\text { Name of } \\
\text { complex }\end{array}$ & $\begin{array}{c}\text { JinXiang He } \\
\text { Complex }\end{array}$ & \multirow{4}{*}{$\begin{array}{l}\text { Structure: Brick- } \\
\text { concrete structure/ } \\
\text { sintered brick as } \\
\text { maintenance } \\
\text { structure }\end{array}$} \\
\hline & $\begin{array}{c}\text { Year of } \\
\text { construction }\end{array}$ & 1995 & \\
\hline & Floor/Story & $\begin{array}{c}\text { 7th/multi- } \\
\text { storey }\end{array}$ & \\
\hline & Floor height & $2.7 \mathrm{~m}$ & \\
\hline \multirow{4}{*}{7} & $\begin{array}{l}\text { Name of } \\
\text { complex }\end{array}$ & $\begin{array}{c}\text { Da Sha Mao } \\
\text { Alley } \\
\text { Complex } 40\end{array}$ & \multirow{4}{*}{$\begin{array}{l}\text { Structure: Brick- } \\
\text { concrete structure/ } \\
\text { sintered brick as } \\
\text { maintenance } \\
\text { structure }\end{array}$} \\
\hline & $\begin{array}{c}\text { Year of } \\
\text { construction }\end{array}$ & 1992 & \\
\hline & Floor/Story & $\begin{array}{c}\text { 7th/multi- } \\
\text { storey }\end{array}$ & \\
\hline & Floor height & $2.7 \mathrm{~m}$ & \\
\hline \multirow{3}{*}{8} & $\begin{array}{l}\text { Name of } \\
\text { complex }\end{array}$ & $\begin{array}{c}\text { Da Sha Mao } \\
\text { Alley } \\
\text { Complex } 38\end{array}$ & \multirow{3}{*}{$\begin{array}{l}\text { Structure: Brick- } \\
\text { concrete structure/ } \\
\text { sintered brick as } \\
\text { maintenance } \\
\text { structure }\end{array}$} \\
\hline & $\begin{array}{c}\text { Year of } \\
\text { construction }\end{array}$ & 80 's & \\
\hline & Floor/Story & $\begin{array}{c}\text { 7th/multi- } \\
\text { storey }\end{array}$ & \\
\hline
\end{tabular}

\begin{tabular}{|c|c|c|c|}
\hline & Floor height & $2.7 \mathrm{~m}$ & \\
\hline \multirow{4}{*}{9} & $\begin{array}{l}\text { Name of } \\
\text { complex }\end{array}$ & $\begin{array}{l}\text { Shuang Jing } \\
\text { Alley complex }\end{array}$ & \multirow{4}{*}{$\begin{array}{l}\text { Structure: Brick- } \\
\text { concrete structure/ } \\
\text { sintered brick as } \\
\text { maintenance } \\
\text { structure/Retrofit } \\
\text { elevator }\end{array}$} \\
\hline & $\begin{array}{c}\text { Year of } \\
\text { construction }\end{array}$ & 1995 & \\
\hline & Floor/Story & $\begin{array}{l}\text { 7th/multi- } \\
\text { storey }\end{array}$ & \\
\hline & Floor height & $2.7 \mathrm{~m}$ & \\
\hline \multirow{4}{*}{10} & $\begin{array}{l}\text { Name of } \\
\text { complex }\end{array}$ & $\begin{array}{l}\text { Sha Tang } \\
\text { Complex }\end{array}$ & \multirow{4}{*}{$\begin{array}{l}\text { Structure: Brick- } \\
\text { concrete structure/ } \\
\text { sintered brick as } \\
\text { maintenance } \\
\text { structure }\end{array}$} \\
\hline & $\begin{array}{c}\text { Year of } \\
\text { construction }\end{array}$ & 1998 & \\
\hline & Floor/Story & $\begin{array}{c}5 \text { th/multi- } \\
\text { storey }\end{array}$ & \\
\hline & Floor height & $2.7 \mathrm{~m}$ & \\
\hline \multirow{4}{*}{11} & $\begin{array}{l}\text { Name of } \\
\text { complex }\end{array}$ & $\begin{array}{l}\text { Cheng Xian } \\
\text { Complex } 92 \\
\end{array}$ & \multirow{4}{*}{$\begin{array}{l}\text { Structure: Brick- } \\
\text { concrete structure } \\
\text { /Facade } \\
\text { reconstruction }\end{array}$} \\
\hline & $\begin{array}{c}\text { Year of } \\
\text { construction }\end{array}$ & 70’s & \\
\hline & Floor/Story & $\begin{array}{c}4 \text { th/multi- } \\
\text { storey }\end{array}$ & \\
\hline & Floor height & $2.8 \mathrm{~m}$ & \\
\hline \multirow{4}{*}{12} & $\begin{array}{l}\text { Name of } \\
\text { complex }\end{array}$ & $\begin{array}{c}\text { Cheng Xian } \\
\text { Complex } 112 \\
\end{array}$ & \multirow{4}{*}{$\begin{array}{l}\text { Structure: Brick- } \\
\text { concrete structure/ } \\
\text { Facade renovation }\end{array}$} \\
\hline & $\begin{array}{c}\text { Year of } \\
\text { construction }\end{array}$ & 50 's & \\
\hline & Floor/Story & $\begin{array}{c}6 \text { th } / \text { multi- } \\
\text { storey }\end{array}$ & \\
\hline & Floor height & $2.8 \mathrm{~m}$ & \\
\hline
\end{tabular}

\section{Surveyed results}

\subsection{Measured results of thermal environments in bathrooms}

\subsubsection{Measured houses and items}

We classified homes built before the 2010 as old homes, and built after 2010 as new homes.

Three typical bathrooms (Tab. 3) were measured: two of them are in old housing complexes, and one in a new complex for comparison purposes. The new house was different from the old houses with respect to the heating devices.

Air temperatures and surface temperatures in the bathrooms were measured in each house.

Table. 2 Measured point

\begin{tabular}{|c|c|c|c|}
\hline R1 & Inner wall & A1 & \\
\cline { 1 - 2 } R2 & Outer wall & A2 & \\
\cline { 1 - 2 } R3 & Yuba & A3 & \multirow{3}{*}{ Air } \\
R4 & Floor & & \\
\hline R5 & Window & A4 & \\
\hline R6 & Hot water & & \\
\hline
\end{tabular}



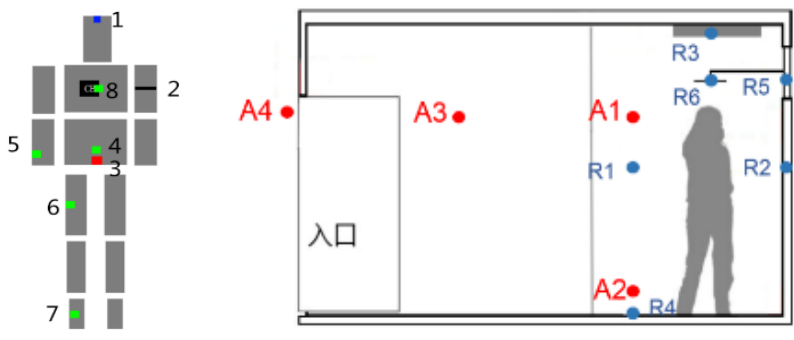

Table. 3 Basic information on three surveyed bathrooms

\begin{tabular}{|c|c|c|c|c|}
\hline No. & & Feature & Remarks & Inside view \\
\hline \multirow{6}{*}{1} & Location & Old complex & Build in 90 's & \\
\hline & Ventilation & Window & & \\
\hline & Heating & Radiation & Top heating & \\
\hline & Floor area & $1.5^{*} 2.5 \mathrm{~m}^{2}$ & $\begin{array}{c}\text { No compartments } \\
\text { inside }\end{array}$ & \\
\hline & Height & $2.4 \mathrm{~m}$ & & \\
\hline & Floor & Ground floor & & \\
\hline \multirow{6}{*}{2} & Location & Old complex & Build in 90 's & \\
\hline & Ventilation & No & & \\
\hline & Heating & Radiation & Top heating & \\
\hline & Floor area & $1.2 * 2.5 \mathrm{~m}^{2}$ & $\begin{array}{c}\text { No compartments } \\
\text { inside }\end{array}$ & \\
\hline & Height & $2.4 \mathrm{~m}$ & & \\
\hline & Floor & First floor & & \\
\hline \multirow{6}{*}{3} & Location & $\begin{array}{c}\text { New } \\
\text { complex in } \\
\text { Nanjing }\end{array}$ & Build in 2015 & \\
\hline & Ventilation & Window & & \\
\hline & Heating & Hot air & Top heating & \\
\hline & Floor area & $1.8^{*} 2.5 \mathrm{~m}^{2}$ & $\begin{array}{l}\text { With compartments } \\
\text { inside }\end{array}$ & \\
\hline & Height & $2.6 \mathrm{~m}$ & & \\
\hline & Floor & $\begin{array}{l}\text { Seventh } \\
\text { floor }\end{array}$ & & \\
\hline
\end{tabular}

Table. 4 Measurement of temperatures

\begin{tabular}{|c|c|c|c|c|c|}
\hline Measurement & No. & Item & Location & Device & $\begin{array}{c}\text { Time } \\
\text { interval }\end{array}$ \\
\hline \multirow{4}{*}{ Body } & 1 & Forehead & Body surface & \multirow{4}{*}{$\begin{array}{l}\text { T-type } \\
\text { thermo- } \\
\text { couple }\end{array}$} & $30 \mathrm{~S}$ \\
\hline & 3 & Rectum & Rectum & & $30 \mathrm{~S}$ \\
\hline & 4 & Belly & Body surface & & $30 \mathrm{~S}$ \\
\hline & 7 & Instep & Body surface & & $30 \mathrm{~S}$ \\
\hline $\begin{array}{c}\text { Thermal } \\
\text { environment } \\
\text { during bathing }\end{array}$ & $\begin{array}{l}\mathrm{A} 1, \mathrm{~A} 2 \\
\mathrm{~A} 3, \mathrm{~A} 4\end{array}$ & \multirow[t]{2}{*}{ Air } & \multirow[t]{2}{*}{ Air } & \multirow{2}{*}{$\begin{array}{c}\text { Tandd } \\
\text { temperatur } \\
\text { e and } \\
\text { humidity } \\
\text { logger }\end{array}$} & $30 \mathrm{~s}$ \\
\hline \multirow{6}{*}{$\begin{array}{c}\text { Daily thermal } \\
\text { environment }\end{array}$} & $\begin{array}{l}\mathrm{A} 1, \mathrm{~A} 2, \\
\mathrm{~A} 3, \mathrm{~A} 4\end{array}$ & & & & $\begin{array}{c}5-30 \\
\text { minutes }\end{array}$ \\
\hline & R1 & Inner wall & Surface & \multirow{5}{*}{$\begin{array}{c}\text { T-type } \\
\text { thermocou } \\
\text { ple }\end{array}$} & $\begin{array}{c}5-30 \\
\text { minutes }\end{array}$ \\
\hline & $\mathrm{R} 2$ & $\begin{array}{c}\text { Exterior } \\
\text { wall }\end{array}$ & Surface & & $\begin{array}{c}5-30 \\
\text { minutes }\end{array}$ \\
\hline & $\mathrm{R} 3$ & $\begin{array}{l}\text { Heating } \\
\text { device }\end{array}$ & Surface & & $\begin{array}{c}5-30 \\
\text { minutes }\end{array}$ \\
\hline & R4 & Floor & Surface & & $\begin{array}{c}5-30 \\
\text { minutes }\end{array}$ \\
\hline & R5 & Window & Surface & & - \\
\hline
\end{tabular}

\subsubsection{Measured air and surface temperatures}

Fig. 4 and Fig. 5 show the measured temperatures in the bathrooms in the old house without a window; Fig.6 shows the results in the old house with a window; and Fig. 7 shows the results in the new house with a window.

The accuracy and response time of the temperature sensor were $\pm 0.1{ }^{\circ} \mathrm{C}\left(-20^{\circ} \mathrm{C}-+80^{\circ} \mathrm{C}\right)$ and $120.0 \mathrm{sec}$, respectively (Tandd data loggers). Other information on the measurement is listed in Tab. 4.

The measurement this time is the first step of our survey. We intend to continue the measurements in order to increase the sample number considering the results this time. From these results, we can notice several features that are probably related to blood pressure.

\section{(1) Vertical temperature difference}

Our measured results show that there are large vertical temperature differences in the bathroom.

In the old bathroom without a window, the maximum air temperature difference between the head and feet was $10.6^{\circ} \mathrm{C}$, and there was also a significant difference between the head and the surface temperature (Fig. 4).

The bathroom with a window in the new house showed that the maximum air temperature difference between the head and feet was $16.6^{\circ} \mathrm{C}$ (Fig. 7), and was greater than that in bathrooms of the old houses. (There were only three spikes for 17 days in the new house, probably because it had two bathrooms, and the residents sometimes used another bathroom.) The temperature difference may be related to differences in the heater types, specifically, radiation type heaters in the old houses and convection type heaters in the new house.

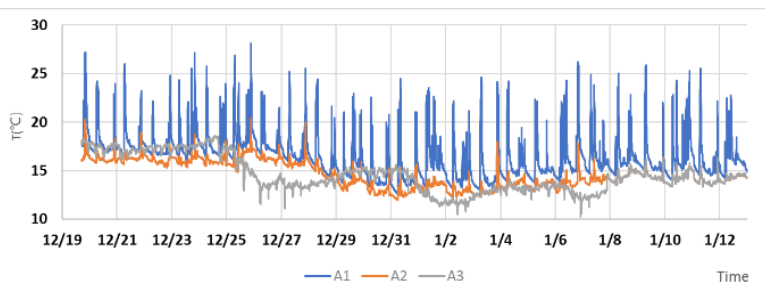

Fig. 4 Temperatures in the old house without windows: winter

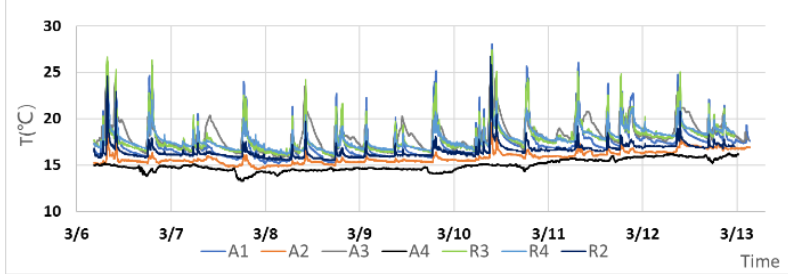

Fig. 5 Temperatures in the old house without windows: March

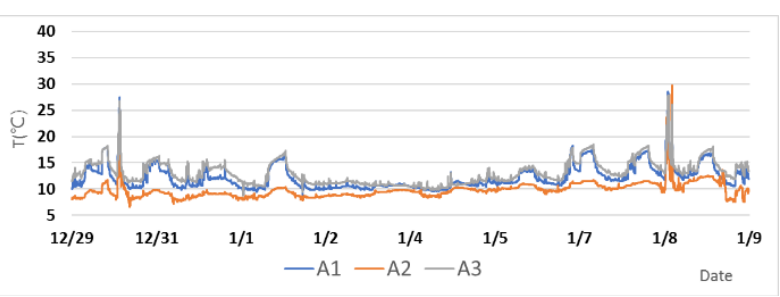

Fig. 6 Temperatures in the old house with windows: winter 


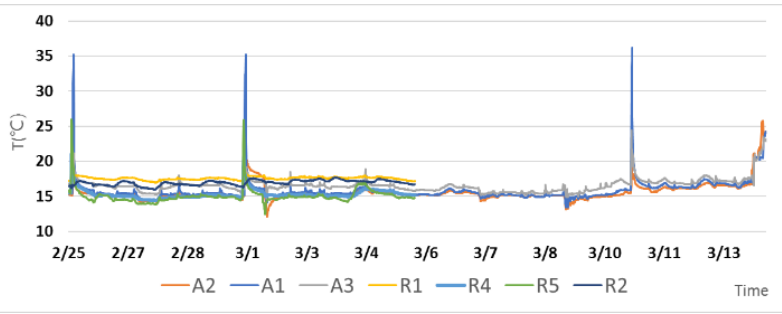

Fig. 7: Temperatures in the new house with windows

(2) Low temperature in bathroom in winter (below $10^{\circ} \mathrm{C}$ )

An air temperature decrease of $40^{\circ} \mathrm{C}$ may increase the systolic blood pressure by $18 \mathrm{mmHg}$ [13].

Nanjing is located in a "cold winter and hot summer" climate zone, meaning that the outdoor temperature is low in winter (Fig. 2). Umishio et al. [14] demonstrate that when the indoor temperature is low, it has an acute effect on blood pressure, and long-term living in a cold indoor environment will also cause long-term effects. This effect becomes more obvious with age $[15,16,17]$. According to our previous survey, most old houses have no insulation (Table 1).

In the bathroom with a window in the old house, the lowest air temperature was $6.6^{\circ} \mathrm{C}$ (Fig.6). In the same period, the bathroom without window in the old house, the lowest temperature was $10.2^{\circ} \mathrm{C}$ (Fig.4). The air leakage, ventilation, and thermal insulation seem to be the factors for this temperature differences. According to the hearing to the residents in the house with window, the window was usually closed in winter. However, one wall and the window faced to the outside, while all of the walls in the bathroom without window did not face to the outside. Thus, the thermal insulation may have had a larger influence on the low temperature. Hozawa et al. [18] investigated the effect of temperature change on blood pressure in different temperatures. They found that in temperatures above $10^{\circ} \mathrm{C}$, temperature and blood pressure had a negative correlation. Madaniyazi et al. [19] demonstrated that the relationship between temperature and blood pressure was V-shaped (although this conclusion is somewhat disputed). Thus, the air temperature may have a complex influence on blood pressure.

\section{(3) Rapid temperature increase during bathing}

The physiological response to a sudden temperature change is rapid. When bathing, the air temperature close to the head rose by $10.1^{\circ} \mathrm{C}$ in 30 minutes in the bathroom without a window in the old house (Fig.8), and $17.2^{\circ} \mathrm{C}$ in 20 minutes in the bathroom with a window in the new house (Fig.9).

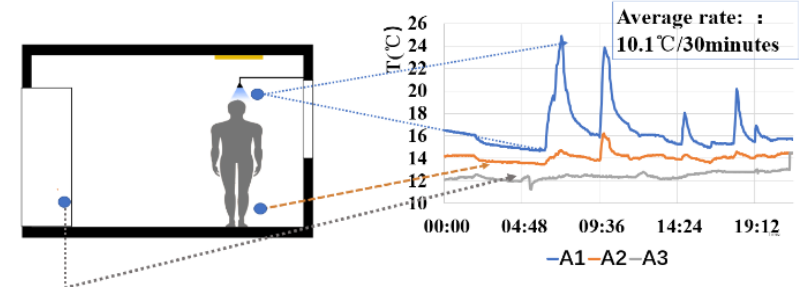

Fig. 8 Temperature change in the bathroom without a window in the old house (winter)

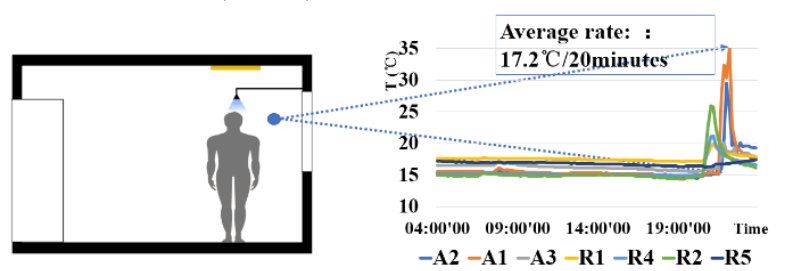

Fig. 9 Temperature change in the bathroom with a window, in the new house (hot air) (winter)

\subsubsection{A preliminary experiment on physiological responses during bathing}

To understand human physiological responses during bathing, we conducted a preliminary bathing experiment in the two house. A university student served as the subject (Tab. 5).

The measurement was conducted twice, once in the new and another in the old house. The first bathing experiment was conducted in the new house for 33 minutes and the second in the old house without window for 38 minutes. 33 minutes after the showering, the core temperature became $38.9^{\circ} \mathrm{C}$ in the first experiment (Fig.10), and $38.4^{\circ} \mathrm{C}$ at the second experiment (Fig.11). The core temperature in both experiments exceeded $38^{\circ} \mathrm{C}$.

Table 5 : Physiological parameters of subject

\begin{tabular}{|c|c|c|c|c|}
\hline Subject & Age & $\begin{array}{c}\text { Height } \\
{[\mathbf{c m}]}\end{array}$ & $\begin{array}{c}\text { Weight } \\
{[\mathbf{k g}]}\end{array}$ & $\begin{array}{c}\text { Mean Rectal } \\
\text { temperature }\left[{ }^{\circ} \mathrm{C}\right]\end{array}$ \\
\hline Student & 27 & 179 & 79 & $37.2^{\circ} \mathrm{C}$ \\
\hline
\end{tabular}

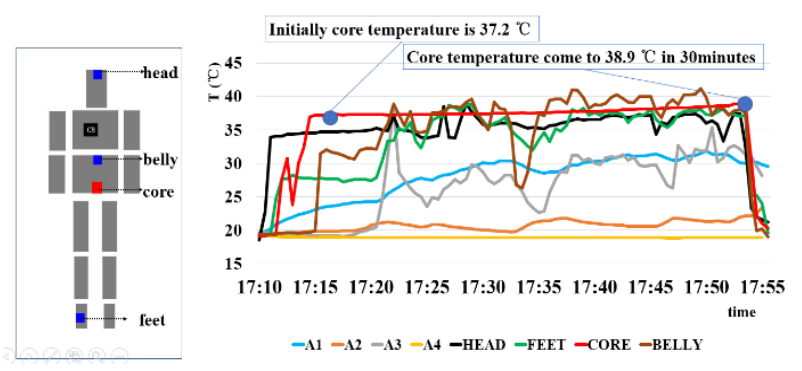

Fig.10. Body temperatures in the bathroom with a window in the new house (hot air heating) (winter)

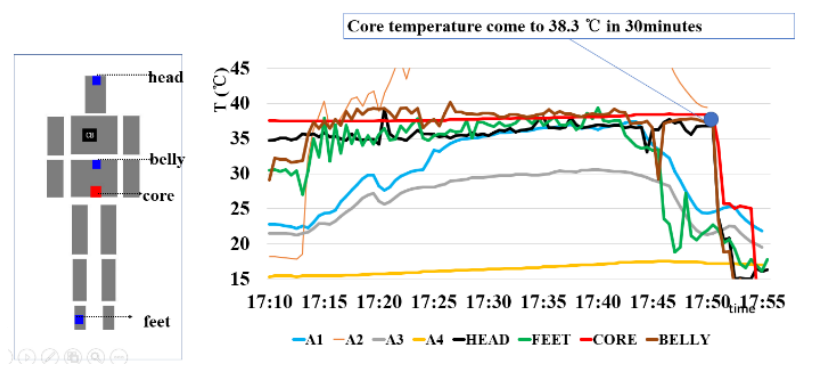

\subsection{Results of the questionnaire survey}

\subsubsection{Bathroom features}

The floor area of the bathroom is between $2.5-4 \mathrm{~m}^{2}(73 \%)$. The bathroom also functions as a toilet and as a space for 
washing clothes. Most of the shower rooms had windows $(84 \%)$. The height of the bathroom is $2.2-2.5 \mathrm{~m}(81 \%)$. The head comes very close to the radiation-type heater installed in the ceiling (Fig. 12).

The heat flow in the bathroom is, in most cases, from the ceiling (87\%), and 13\% from sideways (Fig. 13). While bathing, the elderly have direct contact with walls and devices; thus, the distance between the body and device is an important factor that affects skin temperature.

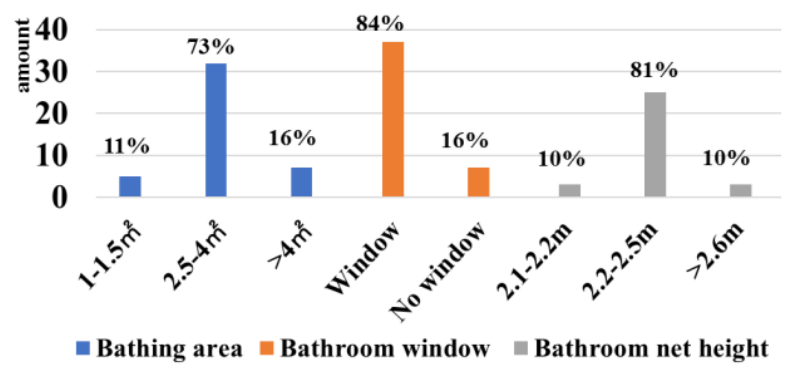

Fig. 12 Attribute of bathroom

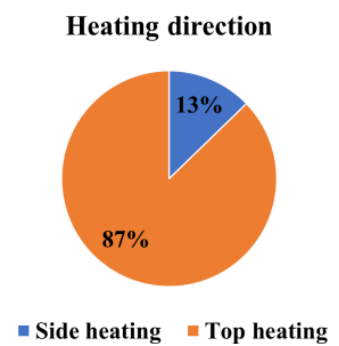

Fig. 13 Direction of heat flow

\subsubsection{Personal factor}

The questionnaire results were summarized focusing on five aspects: bathing time, use of device (affecting indoor thermal environment), contact (affecting partial thermal environment of the body), posture (directly affecting blood flow and blood pressure), and position change (change in thermal environment around the body).

(1) Personal information (physiological and basic information). Among the 49 samples surveyed, 19 were male $(39 \%)$ and 30 were female $(61 \%)$. In this study, the elderly population was divided into 55-65 years old (37\%), 66-75 years old (41\%), and over 76 years old $(22 \%)$. All elderly people that were surveyed had basic self-care living ability.

(2) Household and family information. Old residential houses usually have two bedrooms and one living room $(58 \%)$. Most of these houses have a floor area smaller than $70-80 \mathrm{~m}^{2}(39 \%)$. Among the elderly families in the old housing complexes, the three-generation family comprised the largest portion $(42 \%)$; the second comprised one person and two-person families (38\%).

(3) Health conditions. Circulatory or metabolic diseases are likely to induce shower accidents. The ratio of the elderly having circulatory or metabolic diseases is high. Among the 49 surveyed samples, 19 people are healthy $(42 \%)$, while the remaining $52 \%$ have circulatory and metabolic diseases (Fig. 14).
Table. 6 Basic information on the elderly subjects

\begin{tabular}{|l|c|r|c|}
\hline \multicolumn{1}{|c|}{ Age } & Male & \multicolumn{1}{c|}{ Female } & Pecentage \\
\hline $55-65$ & 8 & 10 & $\mathbf{3 7 \%}$ \\
\hline $66-75$ & 9 & 11 & $\mathbf{4 1 \%}$ \\
\hline Over 76 years old & 2 & 9 & $\mathbf{2 2 \%}$ \\
\hline Total & $\mathbf{1 9}$ & $\mathbf{3 0}$ & \\
\hline Pecentage & $\mathbf{3 9 \%}$ & $\mathbf{6 1 \%}$ & \\
\hline
\end{tabular}

Table. 7 Surveyed house type

\begin{tabular}{|l|l|l|l|l|l|r|r|}
\hline Residence & $\begin{array}{l}<60 \\
\mathrm{~m}^{2}\end{array}$ & $\begin{array}{l}\mathbf{6 0 - 7 0} \\
\mathrm{m}^{2}\end{array}$ & $\begin{array}{l}\mathbf{7 0 - 8 0} \\
\mathrm{m}^{2}\end{array}$ & $\begin{array}{l}\mathbf{8 0}- \\
\mathbf{9 0}\end{array}$ & $\begin{array}{l}>\mathbf{9 0} \\
\mathrm{m}^{2}\end{array}$ & Total & Pecentage \\
& & & & $\mathrm{m}^{2}$ & & & \\
\hline One bedroom & 2 & 0 & 0 & 0 & 0 & 2 & $\mathbf{7 \%}$ \\
\hline Two bedrooms & 6 & 4 & 5 & 2 & 1 & 18 & $\mathbf{5 8 \%}$ \\
\hline Three bedrooms & 0 & 0 & 2 & 2 & 6 & 10 & $\mathbf{3 2 \%}$ \\
\hline Four bedrooms & 0 & 0 & 0 & 0 & 1 & 1 & $\mathbf{3 \%}$ \\
\hline Pecentage & $\mathbf{2 6 \%}$ & $\mathbf{1 3 \%}$ & $\mathbf{2 3 \%}$ & $\mathbf{1 3 \%}$ & $\mathbf{2 6 \%}$ & & \\
\hline
\end{tabular}

Table. 8 Family structure in old housing complexes

\begin{tabular}{|l|r|r|l|l|l|}
\hline & $\begin{array}{l}\text { One } \\
\text { person }\end{array}$ & $\begin{array}{l}\text { Two } \\
\text { persons }\end{array}$ & $\begin{array}{l}\text { Two } \\
\text { generations }\end{array}$ & $\begin{array}{l}\text { Inter- } \\
\text { generational }\end{array}$ & $\begin{array}{l}\text { Three } \\
\text { generations }\end{array}$ \\
\hline Personal & 9 & 9 & 4 & & 6 \\
structure & & & & & 20 \\
\hline Percentage & $\mathbf{1 9 \%}$ & $\mathbf{1 9 \%}$ & $\mathbf{8 \%}$ & $\mathbf{1 3 \%}$ & $\mathbf{4 2 \%}$ \\
\hline
\end{tabular}

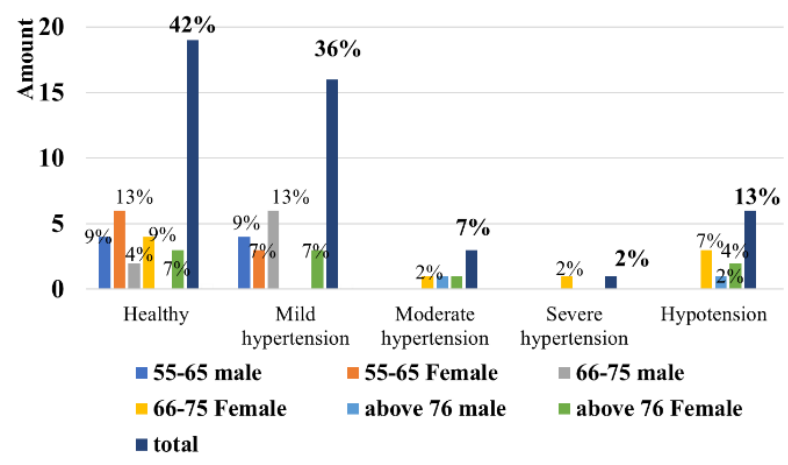

Fig. 14 Physical condition of the elderly

(4) Bathing time (Fig. 15)

There is a big difference in the length of bathing time between seasons. In winter, bathing times are as follows: 10-20 minutes (39\%), 20-30 minutes (27\%), and above 30 minutes $(25 \%)$. We should pay more attention to bathing times longer than 30 minutes because the longer the bathing time, the larger the change in indoor temperature.

The bathing time varies according to age. As age increases, so does the bathing time. In winter, for example, the elderly aged 55-65 that bathed for longer than 20 minutes accounted for (40\%); the elderly aged 66-75 that bathed for longer than 20 minutes accounted for $50 \%$; the elderly aged above 76 that bathed for longer than 20 minutes accounted for $66 \%$.

Additionally, length of bathing time differed according to gender. Female bathing time is generally longer than male bathing time. In the winter, the elderly aged 66-75 who bathed for longer than 20 minutes comprised $33 \%$ male and $63 \%$ female. 


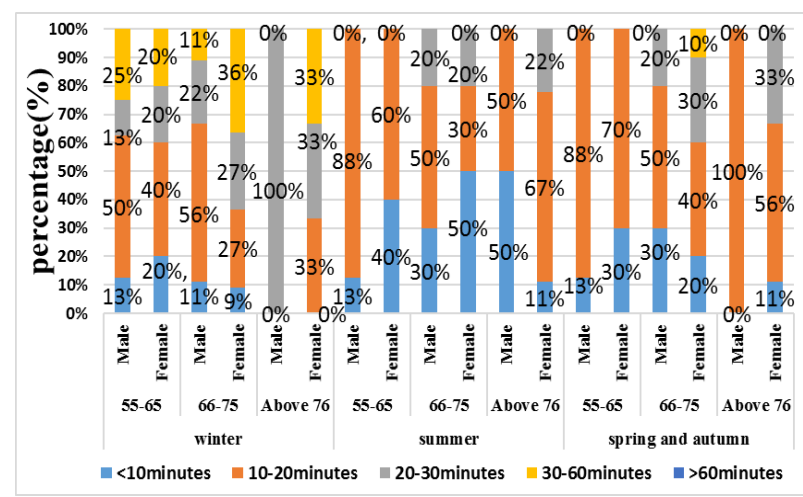

Fig. 15 Length of bathing times of the elderly

\subsubsection{Equipment used}

(1) Heating method. During winter, most elderly people use a radiant type heater $(58 \%)$ for bathing, while a fraction of elderly people are not in the habit of using heating equipment (22\%). A small number of elderly people use other types of heating equipment, such as hot air equipment (Fig. 16).

(2) Bathing facility. Showering is the most popular method of bathing $(90 \%)$. A few people use a bathtub $(6 \%)$, or take a sponge bath, that is, using hot water and a sponge to wipe down their bodies (4\%) (Fig. 17).

(3) Ventilation: Open/Closed windows (Fig. 18). When bathing in winter, most elderly choose to close windows $(36 \%)$, whereas in other seasons, most open the windows $(60 \%-69 \%)$.
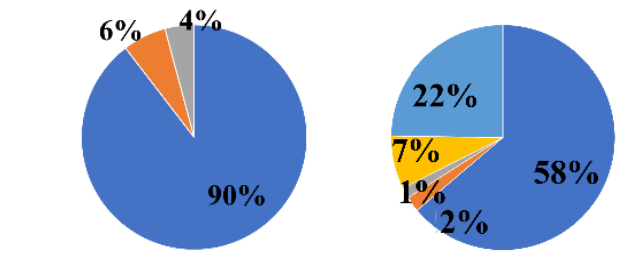

- Radiation heating

not air

- Movable radiation heating

Movable air heating

- No heating equipment or n equipment or no
heating habits

shower $=$ bath in tub $=$ sponge bath

Fig. 16 Heating method

Fig. 17 Bathing facilities during bathing (winter)

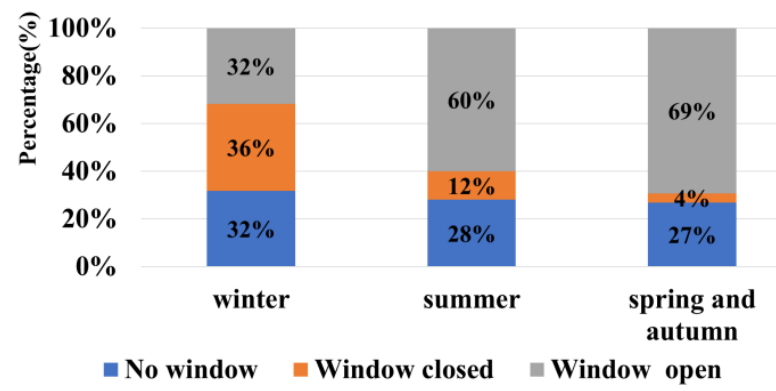

Fig. 18 Open/Closed window during bathing

\subsubsection{Contact with cold object and wearing slippers (partial thermal environment of the body)}

Direct contact between the body and surrounding objects while bathing may also result in blood pressure changes. Most elderly people wear slippers when bathing (90\%). A few elderly people often touched a cold surface when bathing (Fig. 19).
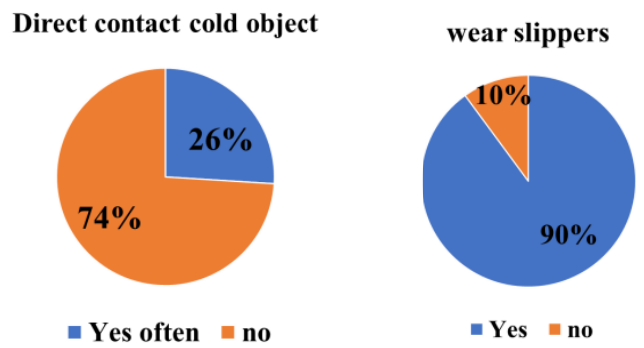

Fig.19 Direct contact and wearing slippers

\subsubsection{Dressing location (sudden changes in thermal environment around the body)}

Several elderly people (90\%) undress/dress in the bathroom so that their skin is not directly exposed to the cold air outside the bathroom. This may be a behavior related to safety; however, a few elderly people (mainly male) did expose their skin directly to the air in the other room after bathing, whose temperature was sometimes very low in winter (Figure 3 - Figure 8), if the people do not operate the air conditioner (Fig. 20).

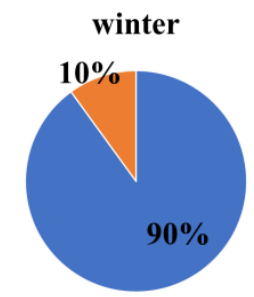

$$
\begin{aligned}
& \text { - dress inside the bathroom } \\
& \text { " dress outside the bathroom }
\end{aligned}
$$

Fig. 20 Dressing location after bathing

\subsubsection{Posture (gravity) change (directly affecting human blood flow and blood pressure)}

There was a sudden change in posture (center of gravity) during bathing in $18 \%$ of the elderly people (Fig. 21), which may cause sudden changes in blood pressure. No obvious age difference was found among these elderly people.

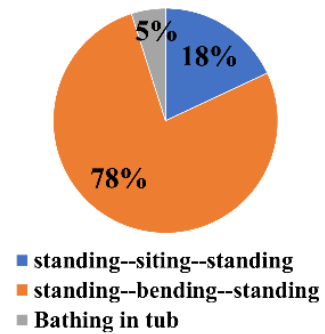

Fig. 21 Posture changes during bathing

\section{Conclusions}

We obtained the following conclusions, but they shall be considered with certain limitation, because the sample number of the measurements is very limited (three). 


\section{Thermal environment factor}

(1) The measurement of the thermal environment in the bathrooms showed non-uniform vertical temperature distribution with the temperature difference usually exceeding $10^{\circ} \mathrm{C}$, temperature change rate exceeding $10^{\circ} \mathrm{C}$ in 30 minutes, air temperature below $10^{\circ} \mathrm{C}$ (with the temperature higher than $10^{\circ} \mathrm{C}$ in the bathrooms without a window in winter. None of the bathrooms had insulation.

(2) During bathing in preliminary bathing experiments, the core temperature of the subject often exceeded $38^{\circ} \mathrm{C}$. Since physiological responses depend on the indivisual and thermal environment, the measured data can be used to check the validity of a human thermophsiological model. Although the sample number is currently very limited, the model is expected to be improved by accumulating this kind of mesurement.

Personal factors. Based on the questionnaire survey, personal factors that may be related to blood pressure changes during bathing were summarized.

(1) Bathing time usually lasted between 10-20 minutes (39\%) in winter, and varied according to age and gender.

(2) Many elderly close the window while bathing in winter $(36 \%)$, and use a radiation type heater attached to the ceiling $(58 \%)$. Most of the elderly choose a shower as their bathing facility (90\%), a few use a bathtub (5\%), and some take a "sponge bath."

(3) Contact with a cold object and posture changes could directly affect the blood pressure during bathing. Most elderly wear slippers (90\%), and do not change their posture drastically while bathing $(78 \%)$. These behaviors are regarded as safe actions.

These results can be used as input parameters for a prediction model of human body temperature and blood pressure.

This research was funded by NSFC (No. 51878140), and the Fundamental Research Funds for the Central Universities ( 3201009202), and Zhong Ying Young Scholar of Southeast University.

\section{References}

1. K. Tsuzuki, et al., Effects of bathing in the mist sauna or sleep in daily life in winter, Humans and Living Environment 19, 101-106 (2012)

2. H. Kubo, et al., Thermal Environment and Health in Toilet of Residential Living 1. Air Conditioning Sanitation Engineering Society, Kinki Branch (2014)

3. Y. Asakawa, R. Takahashi, F. Endo. Cardiovascular Responses during Bathing in the Elderly, Physical Therapy Science, 21-4, 433-436 (2006)

4. Tochihara, et al.: Effects of room temperature on physiological and subjective responses to bathing in the elderly, Journal of the Human-Environment System, 15, 13-19 (2012)

5. Y. Song. Beijing Geriatric Hospital: elderly falls and preventive care, P. 98 (2006)
6. J. L. M. Hensen. Literature review on thermal comfort in transient conditions. Building and Environment, 25(4), 309-316 (1990)

7. P. O. Fanger Thermal comfort. Analysis and applications in environmental engineering, McGrawHill, New York (1972)

8. D. A. Mcintyre. Indoor climate, Applied Science Publishers Ltd, London. (1980)

9. A. P. Gagge, A. P. Fobelets, L. G. Berglund. A standard predictive index of human response to the thermal environment, ASHRAE Transactions, 92:2B, 709-731 (1986)

10. L. Yang, L. Li, S. Lewington, et al. Outdoor temperature, blood pressure, and cardiovascular disease mortality among 23000 individuals with diagnosed cardiovascular diseases from China. European Heart Journal. 36(19), 1178-85 (2015)

11. D. Su, H. Du, X. Zhang, et al. Season and outdoor temperature in relation to detection and control of hypertension in a large rural Chinese population . International Journal of Epidemiology, 43(6), 183545 (2014)

12. M. Fedecostante, P. Barbatelli, F. Guerra, et al. Summer does not always mean lower: seasonality of $24 \mathrm{~h}$, daytime, and night-time blood pressure . Journal of Hypertension, 30 (7), 1392-8 (2012)

13. J. Xiong, Z. W. Lian, H. B. Zhang. Physiological Response to Typical Temperature Step-changes in winter of China. Energy and Building, 138, 687-694 (2017)

14. W. Umishio, T. Ikaga, S. Ando, K. Otsuka. Influence of room temperature on home blood pressure based on multi-level model - A survey of the effect of indoor thermal environment on blood pressure in winter (Part 2)-, Architectural Institute of Japan, 80, 703-710 (2015)

15. S. Lewington, R. Hampel, S. Breitner, et al. Shortterm effects of air temperature on blood pressure and pulse pressure in potentially susceptible individuals. International Journal of Hygiene \& Environmental Health, 217(7), 775-784 (2014)

16. R. Chen, J. Lu, Q. Yu, et al. The acute effects of outdoor temperature on blood pressure in a panel of elderly hypertensive patients. International Journal of Biometeorology, 59(12), 1-7 (2015)

17. A. Alpérovitch, J. O. Lacombe, J. Dartigues, et al. Relationship between blood pressure and outdoor emperature in a large sample of elderly individuals: the Three-City study . Archives of Internal Medicine, 169 (1), 75- 80 (2009)

18. A. Hozawa, S. Kuriyama, T. Shimazu, et al. Seasonal variation in home blood pressure measurements and relation to outside temperature in Japan. Clinical \& Experimental Hypertension, 33(3), 153-8 (2011)

19. L. Madaniyazi, Y. Zhou, S. Li, et al. Outdoor Temperature, Heart rate and Blood Pressure in Chinese Adults: Effect Modification by Individual Characteristics . Scientific Reports, 6, 1-7 (2016) 